\title{
The Conquest of Cattle Dominancy Statuesque in Pastoral Area: A Case of Borana Pastoral in Southern Ethiopia, Ethiopia
}

\author{
Dirriba Mengistu \\ Yabello Pastoral and Dryland Agricultural Research Center, Yabello, Ethiopia
}

Email address:

dmangistu@gmail.com

To cite this article:

Dirriba Mengistu. The Conquest of Cattle Dominancy Statuesque in Pastoral Area: A Case of Borana Pastoral in Southern Ethiopia, Ethiopia. Science Research. Vol. 8, No. 5, 2020, pp. 115-118. doi: 10.11648/j.sr.20200805.13

Received: September 4, 2019; Accepted: December 11, 2019; Published: September 17, 2020

\begin{abstract}
This study was undertaken in Borana zone to evaluate the livestock production and composition using 125 respondents. The sample households were selected randomly from the randomly selected districts and PAs. The result showed that the livelihood diversification is the reality on the ground unlike the pastoralism jargon. The survey data indicated that crop production covers about $22 \%$ of annual income of the Agro/pastoralists. The diversification to the drought resistant livestock and dryland crop farming become expanded in the zone. However, the shift from cattle dominance social system to crop and drought resistant livestock should be examined from economics autonomy besides ecological maintenance. Additionally, this research did not provided attention to the optimization of pastoral livelihood diversification to systemize the natural enforced diversification in the pastoral area. Additionally, this conclusion opens the entry for further investigation to prove the wealth dynamics and asset diversification index in the pastoral area. Thus, it calls for further pastoral economy (income) analysis beyond this study, which demands an integrative research and development interventions to balance the livelihood diversification and ecological balance.
\end{abstract}

Keywords: Borana, Cattle, Diversification, Livestock, Pastoralist

\section{Introduction}

Climate variability is the greatest threat to livestock production system, which recurrently harass asset before full recovery achieved [1]. As a result, Borana pastoralists are much poorer today than they were in decades, as livestock per capita has declined from 4.1 to 2.3 TLU and recently found 1.9 [2, 3]. The decline in livestock per capita [4] and resultant shifts in households' wealth ranks over a period of years reflect the erosion of the pastoral economy [5].

Since recent times, most of the pastoralists strained to diversify into agricultural production [1] even though pastoralism was used to be their main livelihood system. As a result, agro-pastoralists and farming were emerged in Borana zone besides the pastoral farming system.

The Borana pastoralists were practicing small-scale crop farming to fulfill the food requirement of their family even though it is ad hoc gambling game with climate condition. In whatever case, the opportunistic cultivation has become an alternative to partially compensate for such a long-term trend livestock restocking [6]. Increase in cultivation was attributable to a declining ratio of livestock to people as exacerbated by human population growth and drought [7]. Often, the depletion of smaller herds from the poor pastoralists induces the permanently shift into farming unfortunately [8]. Particularly, the drought vulnerability [9] of cattle has been affected the dependency on cattle dominant livelihood system. Thus, this paper focuses on the trends of the livelihood system of the pastoralists from the perspective of cattle asset.

\section{Methodology}

Borana zone is located about $570 \mathrm{~km}$ from Addis Ababa at the Southern tip of Ethiopia. It is characterized by $10 \%$ highland, $20 \%$ temperate and $70 \%$ lowland with the average 
temperature ranges between $18-28^{\circ} \mathrm{C}$ and altitude lying between 500 and $2500 \mathrm{~m}$ asl (Ibrahim, 2005). In this study, the primary data were collected from sample households using a semi-structured questionnaire after survey questionnaires were pre-tested before beginning the actual data collection. To capture better socio-economic context of the area, qualitative data was collected using Focus Groups Discussion (FGD) and key informant interview.

Moreover, secondary data were collected from different organization in the zone to enrich the primary data collected. Descriptive statistics such as mean, percentage and frequency were used to estimate the socio-economic characteristics of the sample households. Chronologically, stratified sampling technique was generally applied to obtain a representative sample for a population from which a sample is to be drawn from a homogeneous group [8]. Accordingly, Borana zone was stratified into three (3) homogeneous group as pastoral, agro-pastoral and agriculture.

From each category, 1-2 sample districts were randomly selected and the selected districts were again stratified into pastoral, agro-pastoral and agriculture Peasant Association (PAs). From these stratified PAs, sample PAs were randomly selected and finally, representative sample households were randomly selected. Based on this, 123 households were drawn out at $95 \%$ CI with 0.5 degree of variability at $9 \%$ precision level [9] plus 17 reserved with 140 household in total. Finally, the respondent households were selected from the PAs on proportionality basis owned to their population.

\section{Result and Discussion}

\subsection{Dynamics of Livestock Asset}

Livestock is the economic basis for pastoral households from history though periodic influences of manmade and natural calamities persistently suppressing. In the pastoral area, besides social recognition still cattle moderately dominate the population of livestock due to its importance for draft power, social value and its product such as milk, butter and meat.

From the customary point of view, cattle were the indicative of social position and the utmost desired for cultural heritage. However, the livestock Per capita is still declining in Borana pastoral area along with its productivity.

The survey result shows that across the occurrence of the drought, the livestock per capita is declining at a rate of 0.71 (Figure 1). On the other hand, current livestock per capita is far below than the recommended sustainable livelihood requirement of either pastoralists or agro-pastoralists. The standard livestock per capita for self-sufficiency by agropastoral households is agreed to be 3-4.1 TLU per person and 7 TLU per person for a pure pastoral community $[10,11]$. Moreover, this study shows that the livestock per capita is about 1.87 (Figure 2), which hints still the declining of livestock per capita. It proves that the numbers of poor pastoral households are increasing overtime [12] unless otherwise the diversification to another livelihood is proven
[17].

The result of the study also shows that though cattle dominates on average, the population of small ruminant outweigh the population of cattle asset in physical quantity. Cattle population followed by goat, sheep and camel respectively dominated the physical quantity of livestock population in Borana. Explicitly, female cattle dominate the male cattle in cattle population.

In the lowland of the study area, though cattle are the dominant livestock type, the demand for the drought resistant livestock types have been increasing from time to time. On average, households have 12.35 livestock (TLU) where cattle cover about $80 \%$ of the asset. However, though about $81 \%$, $80 \%, 67 \%, 46 \%, 33 \%, 2 \%$ and $9 \%$ of the respondents own cattle, Goat, Sheep, Poultry, Donkey, Horse and camel respectively, the livestock per capita is about $1.87 \mathrm{TLU}$. This shows that about $80 \%$ of the households are own cattle and goat due to both are milk sources beyond other benefits.

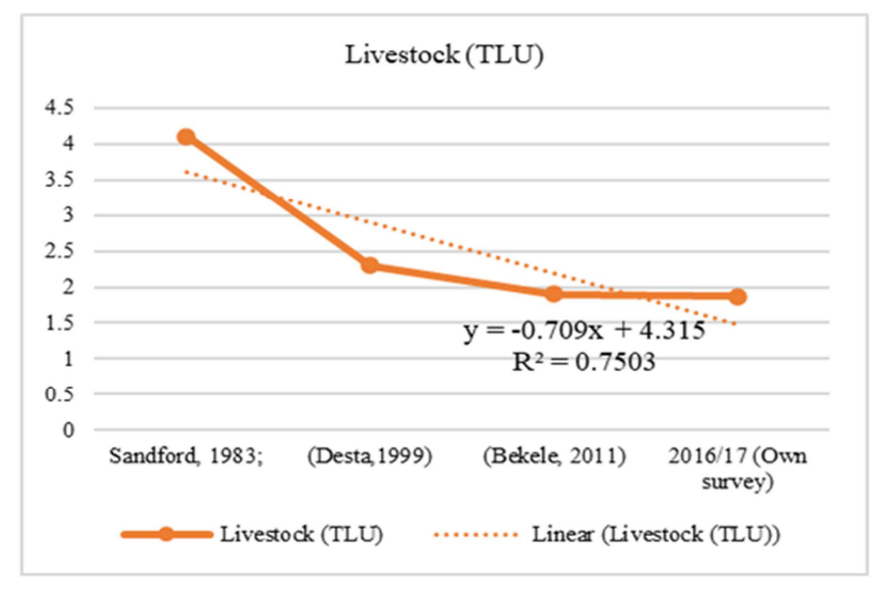

Sources: Publication and own survey.

Figure 1. Trends of livestock owned (TLU).

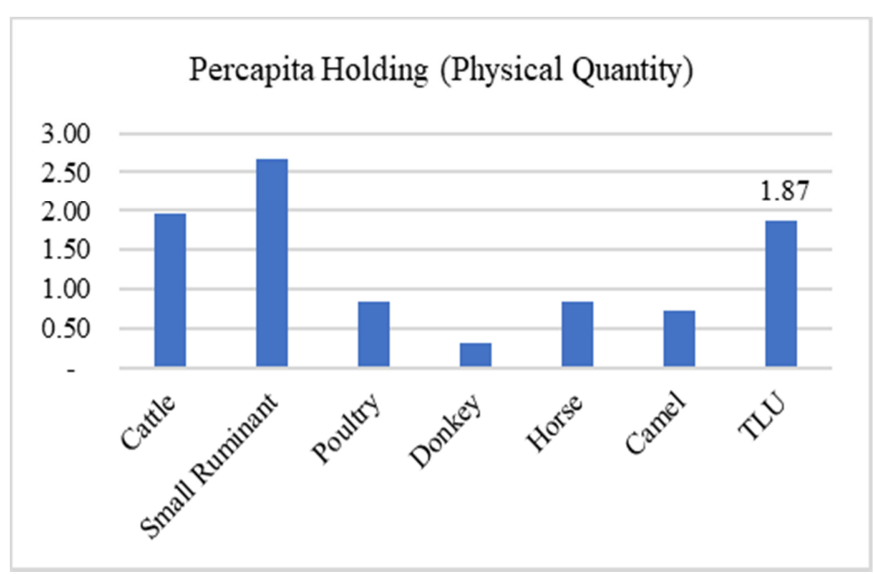

Figure 2. Per capita livestock holding (Physical Quantity).

\subsection{Annual Income Pattern}

The productivity of lactating animal was declined to 10-20 animals, as compared to forty years ago when one or two lactating animals was sufficient to sustain the livelihood of pastoral households [13]. 


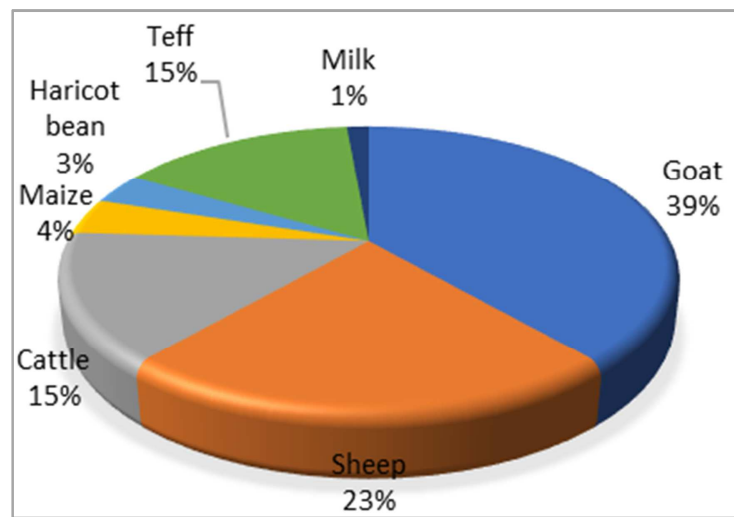

Figure 3. Proportion of agricultural income.

As a result, the livelihood diversification into extraneous livelihood system, particularly dryland farming is increasing overtime [14].

Generally, crop income and small ruminants covers about $20 \%$ and $60 \%$ of annual pastoral income respectively. Moreover, cattle and cattle product cover less than $20 \%$ from the total income of the households. The dependency on crop dominant based livelihood system is, however, hard due to recurrent rain failure [15]. Moreover, though it needs further investigation to explore the deep panel data analysis of agricultural income in the livestock based livelihood system; this research shows that the inclination to small ruminant and crop production is conquering for livestock production in general and cattle in particular.

Beside cash generation, the demands for goat is inflated due to different important characteristics of goat. Anecdotal evidence briefed that goat's milk is highly important for children though it the dominant option where the milk of cattle is in deficient. As a result, consumption of goat milk also highly expanded which makes goat an important animal in the area.

\subsection{Livestock Preference Characterization}

History conveys that livestock is the foundation of cultural, social and economic basis of Borana pastoralists. Particularly, cattle play a leading role in cultural heritage of the society. However, the production preference of the pastoralists was upstate unlike earlier decades. Accordingly, livestock preferences were ranked regarding to the production, consumption and marketing.

Table 1. Livestock preference across various criteria.

\begin{tabular}{|c|c|c|c|c|c|c|c|c|c|}
\hline \multirow{2}{*}{ Livestock category } & \multicolumn{3}{|c|}{ Production } & \multicolumn{3}{|c|}{ Consumption } & \multicolumn{3}{|c|}{ Selling } \\
\hline & $\mathbf{N}$ & $\chi^{2}$ & $\%$ & $\mathbf{N}$ & $\chi^{2}$ & $\%$ & $\mathbf{N}$ & $\chi^{2}$ & $\%$ \\
\hline Cattle & 18 & 5.1 & 16.7 & 7 & .4 & 7.8 & 8 & .38 & 7.8 \\
\hline Cattle, sheep and goat & 2 & & 2.2 & 5 & .83 & 4.4 & 1 & - & 1.1 \\
\hline Cattle, goat and Camel & 16 & $18.6^{*}$ & 13.3 & - & - & - & - & - & - \\
\hline Goat & 9 & 4.1 & 5.6 & 28 & $11^{*}$ & 21.1 & 9 & - & 1.1 \\
\hline Camel & 6 & 6.0 & 4.4 & - & - & - & 16 & $32^{* * *}$ & 17.8 \\
\hline Goat and Cattle & 11 & 5.0 & 11.1 & 5 & - & 5.6 & 12 & - & 14.3 \\
\hline
\end{tabular}

According to this study, the combination of cattle with goat and camel significantly outweigh the production preferences of the society. In production, cattle are preferred by $11 \%$ and $22 \%$ than goat and camel respectively. However, about $72 \%$ of respondents prefer cattle production with a combination with other livestock particularly goat, sheep and camel whereas only $23 \%$ respondents prefer cattle only production system. Similarly, goat is preferred by $26 \%$ and $34 \%$ than cattle and camel respectively for consumption purposes. Note that the preference of consumption for goat is dominantly related to family size, capacity, storage facility (refrigerator) and resource sharing habit of the households.

In a general preference, about $83 \%$ of respondents preferred goat for consumption with other livestock whereas only $44 \%$ of prefer goat only consumption. On the other hand, to generate the higher income, the pastoralists prefer to sell camel, $37 \%$ of the respondent, only due its higher price per unit as compared to other livestock. However, larger parts of the respondents prefer to sell other livestock following the top priority of camel due to its prices.

Generally, due to the demonic suppression of drought on cattle production, the preference of pastoral households was shifted from cattle dominancy to a combination of a drought tolerant livestock types though the importance of cattle outweigh the socio-cultural role. Accordingly, goat, cattle, camel and sheep remain the top priority preferred livestock types in the community respectively. The low productivity of cattle, however, has an implication for food insecurity, which rises the cost of livestock production as compared to its return.

\section{Conclusion and Recommendation}

The livestock Per capita is still declining in Borana zone along its productivity. Though history conveys that livestock is the foundation of cultural, social and economic basis of Borana pastoralists, the production preference of the pastoralists was upset unlike earlier decades. As a result, pastoralists are battling to diversify their livelihood activities from only pastoralism to crop farming owned to decline in the livestock per capita. On the other hand, the inclination to small ruminant and crop production is conquering cattle production.

Additionally, the pastoral households are still practicing the conventional livestock production system in which mobility remains a very important. On the other hand, livelihood diversification expansion become the motive of most pastoralists, which have higher influence on livestock production. 
On the other hand, though Boran cattle is an important foundation of best breed in Africa, the interventions to protect this resource is unsatisfactory beyond the conventional maintenance. With this situation, still the complete dilution and extinction of the pure productive Borana cattle is not too far, otherwise visional intervention should develop.

Thus, R \& D interventions need to draw further attention to improve the carrying capacity for the environment and land along the maintenances of pure Boran cattle. Moreover, the study applauds urgent demands of detail characterization of goat breed (particularly milking goat) as goat become an important source of milk in the area. Moreover, this conclusion opens the entry for further investigation to prove the wealth dynamics and asset diversification index in the pastoral area to protect the pastoral livelihood. Finally, though pastoral economy (income) analysis is beyond the scope of this research, an integrative research and development interventions is critically important to maintain pure borana cattle besides the optimization of pastoral production for sustainable pastoralism.

\section{Acknowledgements}

The author would like to appreciate Oromia Agricultural Research Institute (IQQO) for funding this project. The ideas in this publication is, remains to the responsibility of the authors.

\section{References}

[1] Angassa, Ayana; Oba, Gufu, "Relating long-term rainfall variability to cattle population dynamics in communal rangelands and a government ranch in southern Ethiopia," Journal of Agricultural Systems, vol. 94, pp. 715-175., 2007.

[2] S. Desta, Diversification of livestock assets for risk management in the Borana pastoral system of Southern Ethiopia. Ph.D. Dissertation, department of Rangeland Resources, Logan, Utah State University, 1999.

[3] B. Megersa, Climate change, cattle herd vulnerability and food insecurity: Adaptation through livestock diversification in the Borana pastoral system of Ethiopia. Dissertation, Universität Hohenheim, Faculty of Agricultural Sciences, Institute of Production in the Tropics and Sub-tropics, Department of Animal Breeding and Husbandry., 2013.

[4] D. Mengistu, "Impacts of Drought and Conventional Coping Strategies of Borana Community, Southern Ethiopia,"
Research on Humanities and Social Sciences, vol. 6, no. 23, pp. 29-37, 2016.

[5] P. Little, M. Stone, T. Mogues and A. Castro, "Moving in Place: Drought and poverty dynamics in south Wollo, Ethiopia," Development Studies, vol. 42, no. 2, 2006.

[6] D. Coppock, "The Borana plateau of southern Ethiopia: synthesis of pastoral research, development and change, 1980 - 91 International Livestock Center for Africa, Addis Ababa.," 1994.

[7] B. Tache, "Pastoralism under Stress: Resources, Institutions and Poverty among the Borana Oromo in Southern Ethiopia.," 2008.

[8] W. Berhanu and F. Beyene, "Climate Variability and Household Adaptation Strategies in Southern Ethiopia," Sustainability, vol. 7, pp. 6353-6375, 2015.

[9] M. Dirriba, "Impacts of Drought and Conventional Coping Strategies of Borana Community, Southern Ethiopia.," Journal of Research on Humanities and Social Sciences, vol. 6, no. 23, 2016.

[10] C. Kothari, Research methodology: Methods and techniques, New Age International, 2004.

[11] Y. Tora, "Statistics, an introductory analysis. New York," no. Second Ed.,, 1967.

[12] Dahl, G, Suffering Grass: Subsistence and Society of Waso Borana, Stockholm Studies in Social Anthropology, 1979., p. 191.

[13] S. Sandford, Management of pastoral development in the Third World, New York: Wiley, 1983.

[14] T. J. Lybbert, C. B. Barrett, D. S. and C. D. L, "Stochastic wealth dynamics and risk management among a poor population." Journal of Economics, no. 114489, pp. 750-777, 2004.

[15] A. Napier and S. Desta, "Review of Pastoral Rangeland Enclosures in Ethiopia," 2011.

[16] M. Hurst, N. Jensen, J. Sharma and A. Pendersen, "Changing climate adaptation strategies of Borana pastoralists in southern Ethiopia. CGIAR Research Program on Climate Change, Agriculture and Food Security CCAFS.," vol. 15, 2012.

[17] K. Zander and J. Mburu, Compensating pastoralists for conserving animal genetic resources: The case of borana cattle in ethiopia, Bonn, Germany: Center for Development Research (ZEF), 2004.

[18] A. Tilahun, B. Teklu and D. Hoag, "Challenges and contributions of crop production in agro-pastoral systems of Borana Plateau, Ethiopia," Pastoralism: Research, Policy and Practice, vol. 7, no. 2, 2017. 